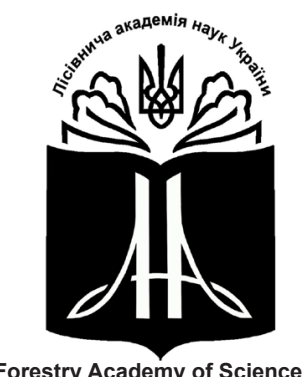

Forestry Academy of

Наукові праці Лісівничої академії наук України Proceedings of the Forestry Academy of Sciences of Ukraine

http://fasu.nltu.edu.ua https://doi.org/10.15421/411807

Article received 2018.03.02

Article accepted 2018.05.31
ISSN 1991-606X print

ISSN 2616-5015 online

(a) $\triangle$ Correspondence author Svitlana Los svitlana los@ukr.net

Pushkinska str., 86, Kharkiv, 61024, Ukraine

УДК 630.165.6

\title{
Комплексне оцінювання перспективності видів і гібридів модрини для умов Лісостепу України
}

\author{
С. А. Лось ${ }^{1}$, В.Г. Григорьєва², В.П. Самодайㄱ, І. С. Нейко ${ }^{4}$
}

Узагальнено дані щуодо комплексного оцінювання лісових культур видів і гібридів модрини у насадженнях Лісостепу Украйни на території трьох областей - Харківської (ДП «Харківська ЛНДС», ДП «Гутянське ЛГ»), Сумської (ДП «Тростянецьке ЛГ», ДП «Свеське ЛГ») та Віннищької (ДП «Віннищьке ЛГ», ДП «Вінницька ЛНДС»). У деревостанах віком 52-124 роки закладено 10 пробних площ. Переважна більшість насаджень розташована у лісостеповій природній зоні за виключенням ДП «Свеське ЛГ», розташоване у Поліській природній зоні.

Об'єкт дослідження - інтродукиія видів та гібридів роду Larix L.

Мета досліджень - оцінювання успішності інтродукиї видів та гібридів модрини у штучних насадженнях Лісостепу України.

У більшості лісових культур види і гібриди модрини переважають дуб звичайний за діаметром (на 4,9-38,5\%) і майже в усіх - за висотою (на 10,6-29,0). Порівняння таксаційних показників модрини і сосни звичайної показало, щзо в n'яти деревостанах модрина переважає сосну за висотою на 3,5-34,9\%, за діаметром-на 0,3-7,7\%. У решті випадків модрина рості подібно до сосни або незначно відстає за висотою та діаметром.

Кліматичні умови Вінниччини і Сумщини є сприятливими для росту і розвитку модрин, тоді як тривалі періоди посухи на Харківщині впливають на них негативно. Суттєвого впливу типу лісорослинних умов на ріст модрини не відмічено, але показники деревостанів, в багатших умовах $\left(D_{2}\right)$ переважно дещзо вищі, ніж у сугрудових типах.

За результатами комплексного оцінювання видів $і$ гібридів модрини у трьох областях України переважна більшість виявилися перспективними для культивування, щя підтверджує придатність модрин для створення лісових культур, захисних насаджень і озеленення в умовах Сумської і Вінницької областей. В умовах Харківщини види і гібриди модрин придатні для створення захисних насаджень і озеленення.

Для ширшого впровадження видів і гібридів модрини у лісове господарство необхідно розширити лісонасінну базу, зокрема, з використанням вихідного матеріалу з плюсових і кращих дерев, відібраних в обстежених деревостанах.

Ключові слова: клімат; інтродукиія; лісові культури; таксаційно-селекиійні показники, перспектива використання.

Лось Світлана Анатоліївна - член-кореспондент Лісівничої академії наук України, кандидат сільськогосподарських наук, завідувач лабораторії селекції. Український науково-дослідний інститут лісового господарства та агролісомеліорації ім. Г.М. Висоцького, вул. Пушкінська, 86, м. Харків, 61024, Україна. Тел.: 057-707-80-77, +38-097-138-97-92. E-mail: svitlana_los@ukr.net

2 Григорьєва Вікторія Георгївна - науковий співробітник ДП «Харківська лісова науково-дослідна станція» Українського науководослідного інституту лісівництва та агролісомеліорації ім. Г. М. Висоцького, вул. Пушкінська, 86, м. Харків, 61024, Україна. Тел.: $057-$ 707-80-30. E-mail: grygorye@rambler.ru

3 Самодай В'ячеслав Петрович - кандидат сільськогосподарських наук, старший науковий співробітник Краснотростянецького відділення Українського науково-дослідного інституту лісівництва та агролісомеліорації ім. Г.М. Висоцького, вул. Нескучанська, 15, м. Тростянець Сумської обл., 42600, Україна. Тел.: +38-067-105-46-42. E-mail: samodayv@ukr.net

4 Нейко Ігор Степанович - кандидат сільськогосподарських наук, заступник директора ДП «Вінницька лісова науково-дослідна станція» Українського науково-дослідного інституту лісівництва та агролісомеліорації ім. Г. М. Висоцького, вул. Максимовича, 39, м. Вінниця, 21036, Україна. Тел.: +38-096-273-63-67. E-mail: ihor_neyko@ukr.net 
Вступ. Види і гібриди модрин, які вирізняються інтенсивним ростом, зарекомендували себе як перспективні для плантаційного лісовирощування деревні рослини в багатьох країнах світу: Швеції (Larsson-Stern, 2003), Великій Британії (Willougby, 2007.), Чexiï (Kobliha, 2013). В Україні модрини $€$ інтродуцентами і в західному регіоні України визнані перспективними для плантаційного лісовирощування (Debryniuk, Krynytskyy, \& Tselen, 2016, Debryniuk, 2017). Незважаючи на те, що в Східній і Центральній Україні модрини не отримали значного розповсюдження, їхні культури виявили тут високу продуктивність і стійкість (Nikitin, 1953, Patlay, 1979, Grygoryeva \& Samoday, 2017).

Варто зауважити, що оцінювання селекційного матеріалу є одним із найважливіших етапів селекційного процесу. Існує багато методичних підходів до оцінки успішності інтродукції видів деревних рослин. Так, під час проведення сортовипробування здійснюють бальну оцінку комплексу показників з наступним визначенням варіантів, які набрали суму балів вищу, ніж контроль. Методики сортовипробування лісових деревних рослин в Україні (Patlaj \& Molotkov, 1994, The method..., 2014) передбачають визначення цілого комплексу різноманітних показників, у т.ч. інтенсивності росту, якості стовбурів і стану, з одного боку, з іншого - оцінювання стійкості до низки чинників (зимостійкість, морозостійкість, посухостійкість, стійкість до пошкоджень шкідниками, хворобами, забруднення повітря). Крім того, значна кількість показників часто ускладнює загальну оцінку.

Оцінювання успішності інтродукції має включати, окрім показників інтенсивності росту, показники стану, якості та наявності репродукції (Wysotska, 2013). Використаний в роботі підхід базувався на комплексній оцінці перспективності використання інтродуцентів у лісокультурній справі. Головними критеріями при цьому були істотні переваги показників їхнього росту перед аборигенними видами за t-критерієм. Суттєво вищі за контроль показники продуктивності, висока якість стовбурів, добра очищуваність від сучків і добрий стан (відсутність хвороб і шкідників), а також здатність продукувати життєздатне насіння вказують на успішність інтродукції виду та його перспективність для впровадження у лісове господарство регіону (Los, Orlovskaya, \& Grygoryeva, 2008).

Дотепер залишається дискусійною відповідь на питання, який вид може бути контролем для породи-інтродуцента за відсутності біологічно близького аборигенного виду в регіоні. На нашу думку, порівняння показників росту і стану насаджень інтродуцентів, які обстежуються, варто здійснювати 3 місцевими видами, які традиційно вирощуються в регіоні у конкретному типі лісорослинних умов, тобто 3 місцевими видами, які інтродукований вид може потенційно замінити у конкретних природних умовах під час створення плантацій інтенсивного вирощування. Зазвичай під час оцінки виробничих лісових культур порів- няння проводять 3 рослинами аборигенного виду, а за їх відсутності - 3 табличними даними (Shvydenko, Savich, Strochinsky, Polyakov, \& Kanunnikov, 1987).

Об'єкти та методика досліджень. Об'єкт дослідження - інтродукція видів та гібридів роду Larix L. Предмет дослідження - оцінювання успішності інтродукції видів та гібридів роду Larix L. в умовах Лісостепу України. Мета досліджень полягала у здійсненні оцінювання успішності інтродукції видів та гібридів модрини в лісові культури Лісостепу України.

Дослідження проведено у трьох областях України - Харківській (ДП «Харківська ЛНДС», ДП «Гутянське ЛГ»), Сумській (ДП «Тростянецьке ЛГ», ДП «Свеське ЛГ») і Вінницькій (ДП «Вінницьке ЛГ», ДП «Вінницька ЛНДС»). У деревостанах віком 52-124 роки закладено 10 пробних площ (ПП). Переважна більшість деревостанів розташована у Лісостеповій частині за винятком ДП «Свеське ЛГ», розташованого у Поліській природній зоні.

Кліматограми Вальтера (рис. 1), побудовані для порівняння кліматичних умов регіонів досліджень, ілюструють, що за досить близьких показників середньомісячних температур повітря існують помітні відмінності за кількістю опадів. Так, річна сума опадів в районі Харкова становить 528, Богодухова -558 , Тростянця - 631, Свеси -603 і Вінниці - 591 мм.

Для здійснення комплексної оцінки деревостанів видів і гібридів роду Larix L. використано дані пробних площ, закладених у лісових культурах. Під час обстеження на пробних площах для кожного дерева визначали діаметр і висоту стовбура, стан дерева, селекційну категорію (СК), наявність вад i пошкоджень. Стан дерев оцінено за шкалою, модифікованою на базі шкал категорій життєздатності дуба та санітарного стану (Volosyanchuk, et al., 2003). Для визначення перспективності видів за комплексом ознак використано уточнені бальні оцінки інтенсивності росту, стану, якості стовбурів та репродуктивного розвитку (Wysotska, 2013, Los, Neyko, Grigorjeva \& Plotnikova, 2012) (табл. 1).

Якісне оцінювання деревостанів базувалася на визначенні частки дерев I і II селекційних категорій за модифікованою шкалою М.М. Вересіна (Molotkov, et al.,1982). Як контроль використано табличні таксаційні показники насаджень дуба звичайного та сосни звичайної (Shvydenko, Savich, Strochinsky, Polyakov, \& Kanunnikov, 1987).

Комплексне оцінювання насаджень базувалося на сумі балів, визначених за середніми значеннями кількісних і якісних показників для досліджених пробних площ за наступною шкалою: 1) малоперспективні або непридатні (5,0-11,5 балів); 2) відносно перспективні - придатні для створення захисних насаджень і озеленення (11,6-18,5 балів); 3) перспективні - придатні для створення лісових культур, захисних насаджень і озеленення (18,6-25 балів). 


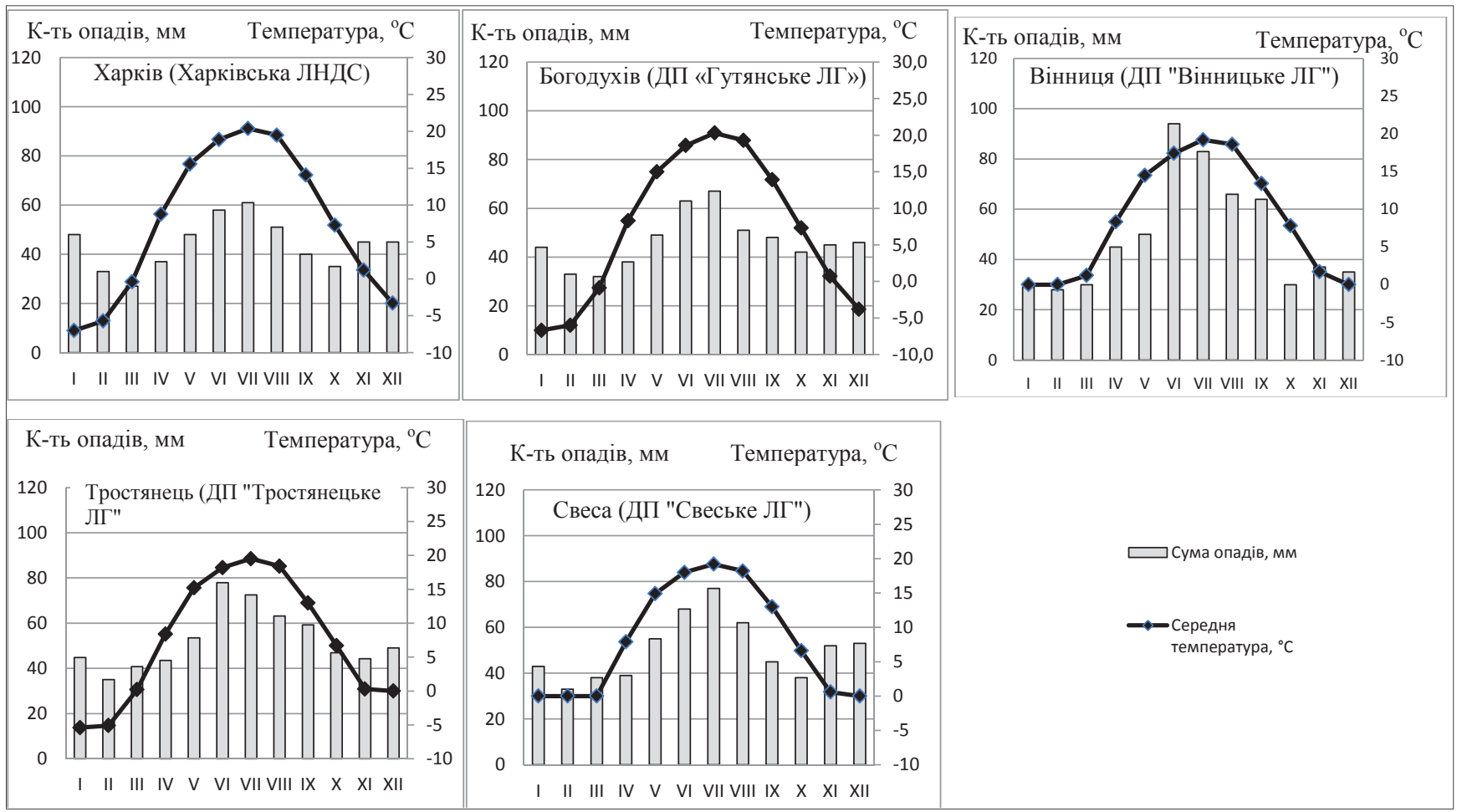

Рис. 1. Кліматограми Вальтера, побудовані для регіонів досліджень

Таблиияя 1

Комплексне оцінювання насаджень видів і гібридів модрини

\begin{tabular}{|c|c|c|c|c|c|}
\hline Бали & $\begin{array}{c}\text { Інтенсивність росту } \\
\text { за висотою }\end{array}$ & $\begin{array}{c}\text { Інтенсивність росту } \\
\text { за діаметром }\end{array}$ & Якість стовбурів & $\begin{array}{l}\text { Стан, } \\
\text { бали }\end{array}$ & $\begin{array}{l}\text { Репродуктивний } \\
\text { розвиток }\end{array}$ \\
\hline 1 & $\begin{array}{c}\text { повільнорослі (відстають } \\
\text { від контролю на 10,1\% і } \\
\text { більше) }\end{array}$ & $\begin{array}{c}\text { повільнорослі (відстають } \\
\text { від контролю на 30,1\% і } \\
\text { більше) }\end{array}$ & $\begin{array}{c}\text { дерева I-II } \\
\text { селекційних } \\
\text { категорій відсутні }\end{array}$ & $4,5-5,0$ & не цвітуть \\
\hline 2 & $\begin{array}{c}\text { відносно середньорослі } \\
\text { (відстають від контролю } \\
\text { на 4,0-10,0\%) }\end{array}$ & $\begin{array}{c}\text { відносно середньорослі } \\
\text { (відстають від контролю } \\
\text { на } 10,0-30,0 \%)\end{array}$ & $\begin{array}{c}\text { частка дерев } \\
\text { I-II селекційних } \\
\text { категорій } 1-10,0 \%\end{array}$ & $3,5-4,4$ & $\begin{array}{c}\text { цвітуть, } \\
\text { але насіння } \\
\text { не утворюють }\end{array}$ \\
\hline 3 & $\begin{array}{c}\text { середньорослі (на рівні } \\
\text { контролю різниця } \\
\text { до 4,0\%) }\end{array}$ & $\begin{array}{c}\text { середньорослі (на рівні } \\
\text { контролю різниця } \\
\text { до } 10,0 \% \text { ) } \\
\end{array}$ & $\begin{array}{c}\text { частка дерев } \\
\text { I-II селекційних } \\
\text { категорій 10,1-15,0\% }\end{array}$ & $2,5-3,4$ & $\begin{array}{c}\text { утворюють } \\
\text { насіння, але воно } \\
\text { нежиттєздатне }\end{array}$ \\
\hline 4 & $\begin{array}{c}\text { відносно швидкорослі } \\
\text { (переважають контроль } \\
\text { на 4,0-10,0\%) }\end{array}$ & $\begin{array}{c}\text { відносно швидкорослі } \\
\text { (переважають контроль } \\
\text { на } 10,0-30,0 \%)\end{array}$ & $\begin{array}{c}\text { частка дерев } \\
\text { I-II селекційних } \\
\text { категорій 15,1-20,0\% }\end{array}$ & $1,5-2,4$ & $\begin{array}{c}\text { утворюють } \\
\text { життєздатне } \\
\text { насіння, але не } \\
\text { дають самосіву }\end{array}$ \\
\hline 5 & $\begin{array}{c}\text { швидкорослі } \\
\text { (переважають контроль } \\
\text { на } 10,1 \% \text { і більше) }\end{array}$ & $\begin{array}{c}\text { швидкорослі } \\
\text { (переважають контроль } \\
\text { більш ніж на 30,1\%) }\end{array}$ & $\begin{array}{c}\text { частка дерев I-II } \\
\text { селекційних категорій } \\
\text { 20,1\% і більше }\end{array}$ & $1,0-1,4$ & $\begin{array}{c}\text { утворюють } \\
\text { життєздатне } \\
\text { насіння, } \\
\text { дають самосів }\end{array}$ \\
\hline
\end{tabular}

Результати досліджень. Основні лісівничотаксаційні та селекційні показники досліджених об'єктів представлені в табл. 2. Середні висота і діаметр вказані для модрини. Детальніша характеристика обстежених у Сумській обл. деревостанів представлені у роботі Grygoryeva \& Samoday (2017).

У Харківській обл. було обстежено дві ділянки лісових культур модрини, чисті за складом. Деревостан у Південному лісництві ДП «Харківська ЛНДС» в умовах свіжої діброви, представлений сумішшю декількох видів модрини (м. європейська, м. сибірська, м. Сукачова, м. даурська, м. Чеканов- ського), у віці 52 роки характеризувався середньою продуктивністю та доброю якісною структурою. Другий деревостан у Шарівському лісництві ДП «Гутянське ЛГ», представлений модриною європейською, в умовах свіжої судіброви виявися продуктивнішим. Частка дерев I і II селекційних категорій також досить висока і становить $40 \%$.

Чотири деревостани за участю модрин європейської і сибірської, обстежені в Сумській обл. у віці 100-129 років характеризувалися високою продуктивністю та якісною селекційною структурою. Їхній загальний запас становив від $618 \mathrm{~m}^{3} \bullet \mathrm{a}^{-1}$ до 
$924 \mathrm{~m}^{3} \bullet \mathrm{ra}^{-1}$, модрини - від $355 \mathrm{~m}^{3} \bullet \mathrm{ra}^{-1}$ до $548 \mathrm{~m}^{3} \bullet \mathrm{ra}^{-1}$. Частка модрини у складі насаджень складає від 5 до 6 одиниць. Незважаючи на значний вік, вони перебувають у задовільному стані, хоча в окремих деревостанах (ПП № 3) в ДП «Тростянецьке ЛГ» відмічене всихання модрини, що зумовлено, в основному, міжвидовою конкуренцією між модриною та ясенем. Таке явище ще раніше відмічав у своїх дослідженнях Lavrinenko (1970).

За селекційною структурою три деревостани виявилися високоякісними (ПП № $3,5,6$ ). В об- стежених насадженнях у різні роки було відібрано 17 плюсових дерев модрини. Завдяки високим таксаційно-селекційним показникам, деревостану в кв. 4, в. 9 Тростянецького лісництва у 2010 р. надано статус плюсового (Grygoryeva \& Samoday, 2017).

Порівняння показників росту модрини і сосни звичайної, яка росте в тому ж самому деревостані, за t-критерієм суттєвої різниці не виявило. За середнім діаметром модрина відстає від сосни звичайної на $6 \%$, а середня висота цих видів досить подібна (рис. 2, ПП №3).

Таблиия 2

Таксаційна характеристика обстежених деревостанів за участю модрини

\begin{tabular}{|c|c|c|c|c|c|c|c|c|c|}
\hline $\begin{array}{l}\text { № } \\
\text { ПП }\end{array}$ & $\begin{array}{l}\text { Лісництво, } \\
\text { кв., вид. }\end{array}$ & Склад & $\begin{array}{l}\text { Вік, } \\
\text { років }\end{array}$ & ТЛУ & $\begin{array}{l}\text { H cep, } \\
\text { м }\end{array}$ & $\begin{array}{l}\text { D cep, } \\
\text { cm }\end{array}$ & $\begin{array}{l}\text { Запас*, } \\
\text { м/гa }\end{array}$ & $\begin{array}{c}\text { Частка } \\
\text { дерев } \\
\text { I та II CK, \% }\end{array}$ & $\begin{array}{l}\text { Індекс } \\
\text { стану, } \\
\text { бали }\end{array}$ \\
\hline \multicolumn{10}{|c|}{ Харківська обл., ДП «Харківська ЛНДС» } \\
\hline 1 & Південне, 118, 11 & 10Мд (суміш видів) & 52 & $\mathrm{D}_{2}$ & 19,8 & 22,5 & $391 / 391$ & 34 & 2,4 \\
\hline \multicolumn{10}{|c|}{ Харківська обл., ДП «Гутянське ЛГ» } \\
\hline 2 & Шарівське, 24, 5 & 10Мде & 92 & $\mathrm{C}_{2}$ & 27 & 32,3 & $517 / 517$ & 40 & 2,5 \\
\hline \multicolumn{10}{|c|}{ Сумська обл., ДП «Тростянецький лісгосп» } \\
\hline 3 & Тростянецьке, 4, 9 & 6Сз4Мде + Дз, Клг & 114 & $\mathrm{C}_{2}$ & 34,5 & 41,8 & $357 / 745$ & 31,8 & 2,4 \\
\hline 4 & Нескучанське, 71, 15 & $\begin{array}{c}\text { 6Мдс3Ясз1Клг } \\
\text { + Дз, Лпд }\end{array}$ & 129 & $\mathrm{C}_{2}$ & 37,8 & 45,6 & $548 / 910$ & 14,7 & 2,6 \\
\hline 5 & Нескучанське, 13, 4 & 5Мдс4Ясз1Дз & 124 & $\mathrm{C}_{2}$ & 36,5 & 42,4 & $355 / 618$ & 70 & 2,5 \\
\hline \multicolumn{10}{|c|}{ Сумська обл., ДП «Свеський лісгосп» } \\
\hline 6 & Свеське, 4, 10 & $6 \mathrm{M} д є 4 \mathrm{C}_{3}+\mathrm{B}_{3}$ & 100 & $\mathrm{D}_{2}$ & 36,2 & 51,2 & $427 / 924$ & 100 & 1,7 \\
\hline \multicolumn{10}{|c|}{ Вінницька обл., ДП «Вінницька ЛНДС» } \\
\hline 7 & Турбівське, 52, 6 & 6Мдє2Дз2Ясз & 105 & $\mathrm{D}_{2-3}$ & 33,8 & 52,4 & $261 / 480$ & 75 & 1,1 \\
\hline \multicolumn{10}{|c|}{ Вінницька обл., ДП «Вінницький лісгосп» } \\
\hline 8 & Вінницьке, 10, 3 & $\begin{array}{c}5 \mathrm{Mдє4Гз} 1 \text { ляя } \\
+ \text { В3, Ясз }\end{array}$ & 60 & $\mathrm{D}_{2}$ & 28,5 & 36,7 & $174 / 321$ & 23,5 & 1,7 \\
\hline 9 & Демидівське, 26, 6 & $\begin{array}{c}\text { 5Мдг2Вз1Ясз1Лпд1Грз } \\
+ \text { Клп, Бп, Сз }\end{array}$ & 70 & $\mathrm{D}_{2}$ & 28 & 31,9 & $170 / 356$ & 41,9 & 2,2 \\
\hline 10 & Гніванське, 43, 9 & $5 \mathrm{Mдє5Дз} \mathrm{+} \mathrm{В3,} \mathrm{Чз,} \mathrm{Клг}$ & 113 & $\mathrm{D}_{2}$ & 33 & 50,4 & $104 / 214$ & 58,3 & 2,3 \\
\hline
\end{tabular}

*запас модрини / загальний запас

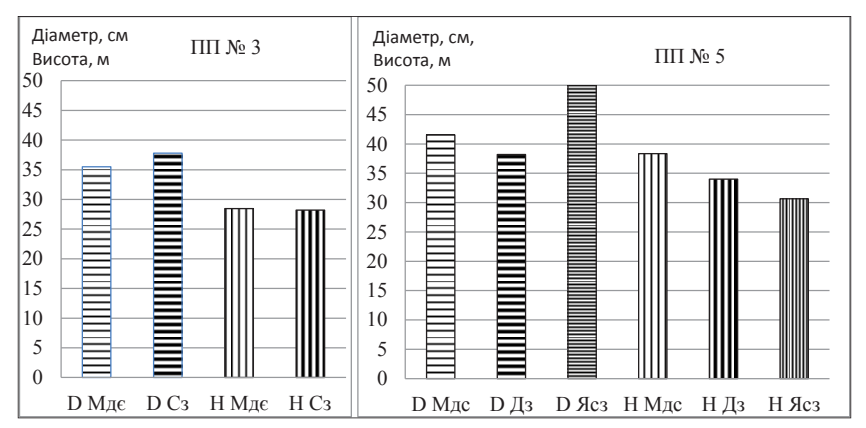

Рис.2. Порівняння діаметрів і висот модрини та аборигенних видів деревних рослин на ПП № 3 і 5

Порівняння середніх висоти та діаметра модрини 3 дубом звичайним та ясенем звичайним на ПП № 5 (див. рис. 2) виявило суттєві переваги модрини за висотою над обома видами (на 12,8 та 25,1 \%, відповідно). За середнім діаметром модрина несуттєво переважає дуб звичайний і дещо відстає від ясена звичайного (на 8,7 і 17,8\%, відповідно).

Обстежені у Вінницькій обл. чотири деревостани за участю модрини європейської та гібридної (шишки з ознаками сибірської та європейської модрин) у віковому діапазоні 60-113 років характеризуються високими таксаційними показниками. Частка дерев I та II селекційних категорій висока (23,5-75\%), переважна більшість дерев перебуває в доброму стані (бал санітарного стану - 1,1-2,3). У насадженнях відібрано 28 особин модрин європейської та гібридної - кандидатів у плюсові дерева.

Порівняння таксаційних показників модрини за даними всіх пробних площ 3 табличними показниками дуба звичайного відповідного віку (рис. 3а) показало, що в половині випадків модрина переважає дуб за діаметром і майже в усіх (за винятком ПП № 1 і ПП № 10) - за висотою. Перевищення за 
висотою становлять $10,6-29,0 \%$, а за діаметром 4,9-38,5\%.

Порівняння таксаційних показників модрини 3 табличними показниками сосни звичайної того ж самого віку (рис. 3б) показало, що на п’яти 3 десяти пробних площ модрина переважає сосну за діаметром і лише в декількох - за висотою. У решті випадків модрина росте на рівні сосни або незначно відстає від неї. На представленому рисунку чітко виділяються три найкращі деревостани (ПП №2, 6 та 7), в яких перевищення за висотою становлять від 0,3 до 12,7, а за діаметром - від 3,5 до 34,9\%.

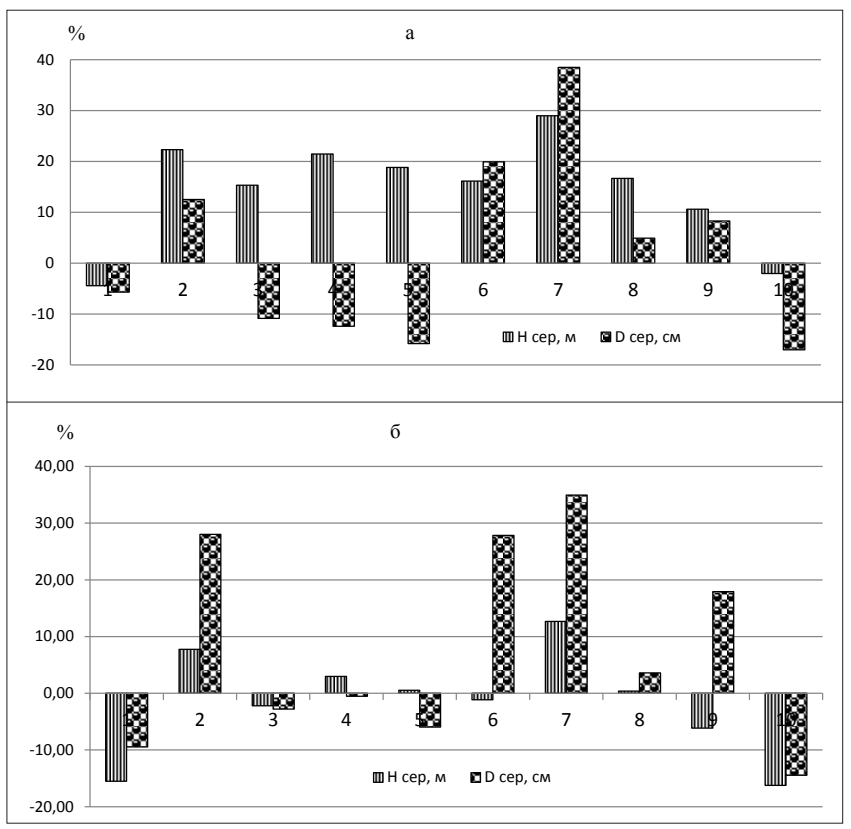

Рис.3. Перевищення таксаційних показників модрини в порівнянні з табличними даними одновікових деревостанів дуба звичайного (а) і сосни звичайної (б)

Результати комплексного оцінювання обстежених деревостанів представлені на рис. 4.

Як бачимо (рис. 4a), в першому випадку сума балів обстежених пробних площ становила від 17,5 (Південне л-во) до 23,3 (Вінницьке л-во). Переважна більшість деревостанів модрини (8 з 10) увійшли до групи перспективних. Серед них найкращими не лише за інтенсивністю росту, але й за селекційною структурою виявилися ПП № 7 (Турбівське л-во ) i ПП № 8 (Вінницьке л-во). До групи відносно перспективних включено два деревостани 3 Харківської обл. (Південне та Шарівське л-ва).

Дерева модрини в усіх обстежених деревостанах утворюють життєздатне несіння.

Під час комплексного оцінювання лісових культур, у порівнянні з табличними даними сосни звичайної, сума балів обстежених пробних площ становила від 15,5 (Шарівське л-во) до 23,3 (Вінницьке л-во) (рис 4б). Переважна більшість деревостанів модрини (6 з 10) увійшли до групи перспективних. Найкращими за комплексом ознак виявилися ті ж самі деревостани, що і в попередньому випадку. До групи відносно перспективних включено чотири деревостани: ДП «Харків- ська ЛНДС», ДП «Гутянське ЛГ» і два деревостани $з$ ДП «Тростянецьке ЛГ».

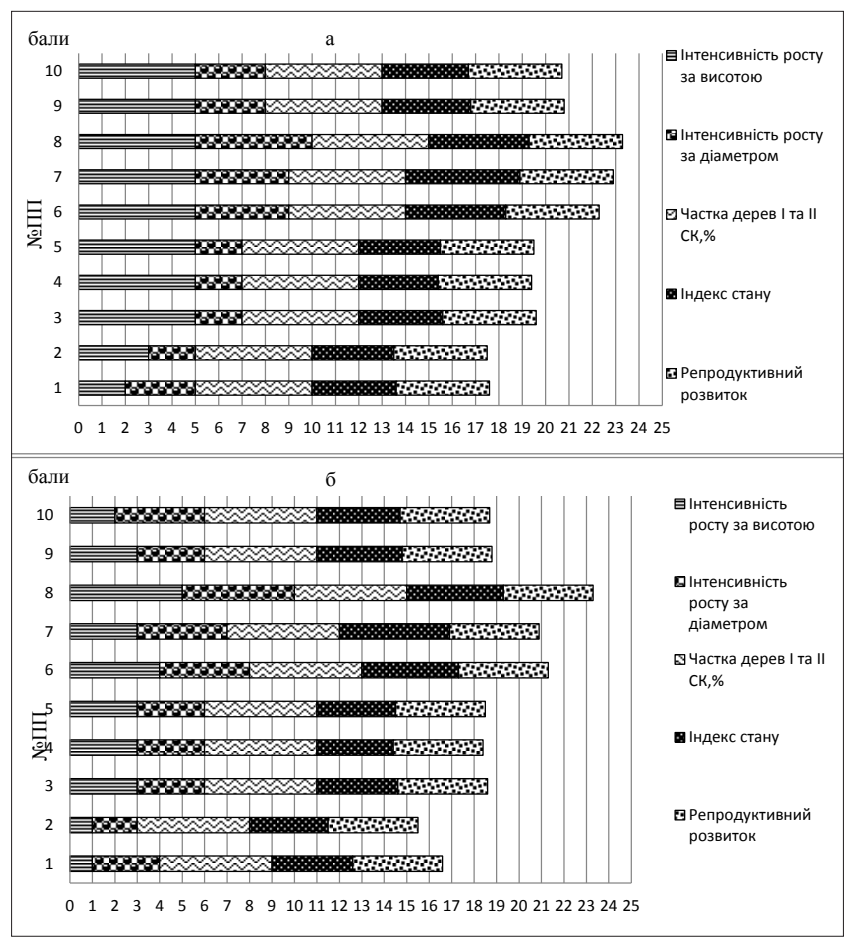

Рис. 4. Результати комплексного оцінювання модрини у порівнянні з табличними даними

по дубу звичайному (а) і сосні звичайній (б)

Варто зазначити, що суттєвих відмінностей у результатах оцінювання під час порівняння як 3 сосною звичайною, так і з дубом звичайним не відзначено, що вказує на можливість використання як контролю під час оцінювання лісових культур модрини, табличних даних обох видів.

Гірший ріст модрини в умовах Харківської обл. можна пояснити континентальнішими кліматичними умовами, зокрема, посушливішим вегетаційним періодом, що добре демонструють кліматограми Вальтера (див. рис 1). Кліматичні умови територій лісових господарств Сумської і Вінницької областей, де були здійснені дослідження, досить подібні, не зважаючи на значну відстань між ними, і є сприятливішими для росту і розвитку модрин. Вплив суми опадів на інтенсивність росту за висотою значний $(\mathrm{r}=0,85)$, тоді як на інтенсивність росту за діаметром майже відсутній (рис. 5), відмічена лише певна тенденція $(\mathrm{r}=0,24)$.

Аналізуючи вплив типів лісорослинних умов, потрібно зазначити, що таксаційні показники деревостанів у багатших умовах $\left(D_{2}\right)$ переважно вищі, що цілком зрозуміло. Сильний позитивний вплив багатства грунту виявлено на інтенсивність росту модрин за діаметром $(\mathrm{r}=0,82)$, середній - на стан $(\mathrm{r}=0,64)$ і на показник суми балів при комплексному оцінюванні $(\mathrm{r}=0,58)$ (див. рис. 5).

Переважна більшість деревостанів у різних регіонах представлена модриною європейською. Окремі ділянки лісових культур цього виду були оцінені як мінімальною, так і максимальною сумою балів. 
Два деревостани модрини сибірської, обстежені в Нескучанському лісництві ДП «Тростянецьке ЛГ», як і деревостан модрини гібридної в Демидівському л-ві ДП «Вінницьке ЛГ» характеризувалися однаковою сумою балів і виявилися перспективними. Загалом відмінностей між видами і гібридами модрини нашими дослідженнями не встановлено.

Інтенсивність росту
Сума балів
Інтенсивність росту
за діаметром, бали

Рис. 5. Вплив багатства грунту ділянки та суми опадів на результати комплексного оцінювання лісових культур модрини

Висновки. В умовах Лісостепу України у половині досліджених насаджень види і гібриди модрини переважають табличні показники як дуба звичайного, так і сосни звичайної за діаметром. Перевищення становлять від 3,5 до $38,5 \%$. У переважній більшості випадків модрина росте за висотою на рівні табличних показників сосни звичайної або незначно відстає від неї, одночасно перевищуючи показники дуба звичайного на 0,3-29,0\%.

За результатами комплексного оцінювання деревостанів за участю модрин європейської, сибірської та гібридної віком 52-124 роки в трьох областях України переважна більшість виявилися перспективними, що підтверджує придатність модрин європейської, сибірської та гібридної для створення лісових культур, захисних насаджень і озеленення в умовах Сумської і Вінницької областей. В умовах Харківщини види і гібриди модрин придатні для створення захисних насаджень і озеленення. Достовірних відмінностей за селекційно-таксаційними показниками між видами і гібридами модрини нашими дослідженнями не виявлено.

Кліматичні умови Вінниччини і Сумщини є сприятливими для росту видів і гібридів модрини, тоді як тривалі періоди посухи на Харківщині впливають на них негативно. Виявлено значний вплив суми опадів на інтенсивність росту модрин за висотою $(\mathrm{r}=0,85)$.

Таксаційні показники видів і гібридів модрини в багатших умовах $\left(D_{2}\right)$ переважно вищі. Сильний позитивний вплив багатства грунту виявлено на інтенсивність росту модрин за діаметром $(\mathrm{r}=0,82)$, середній - на стан $(\mathrm{r}=0,64)$ і на показник суми балів при комплексному оцінюванні $(\mathrm{r}=0,58)$.

Для ширшого впровадження видів і гібридів модрини у лісове господарство необхідним є розширення лісонасінної бази, зокрема 3 використанням репродуктивного матеріалу 3 плюсових і кращих дерев, відібраних в обстежених деревостанах.

\section{Бібліографічні посилання}

Debryniuk, Iu. (2017). Plantation forestry and energy plantations in Ukraine: resource potential and development prospects. The Scientific Bulletin of UNFU, 27 (8), 45-51 (in Ukrainian).

Debryniuk, Iu., Krynytskyy, H., \& Tselen, Ya. (2016). Technology of planting forest plantations in the western region of Ukraine. Lviv: Kamula (in Ukrainian).

Grygoryeva, V., Samoday, V. (2017). Current status of larch plus trees in the Sumy region. Forestry and forest melioration, 131, 67-77 (in Ukrainian).

Kobliha, J. (2013). Selection of European larch provenances based on productivity and economic value. Journal of forest science, 11, 424-435.

Larsson-Stern, M. (2003). Larch in commercial Forestry: A Literature Review to help clarify the potential of hybrid larch (Larix x eurolepis Henry) in Southern Sweden. Southern Swedish Forest Research Centre. 34 p. Retrieved from: https://pub.epsilon.slu. se/441/2/Lic1Larsson-Stern.pdf

Lavrinenko, D. (1970). Creation of forest plantations in the otters of Ukraine. Kyiv: Harvest (in Ukrainian).

Los, S., Neyko, I., Grygoryeva, V. \& Plotnikova, O. (2012) The testing results of 25-years Englich Oak plus trees progenies in the Khmelnick region. Forestry and forest melioration, 120, 44-50 (in Ukrainian).

Los, S., Orlovskaya, T., Grygoryeva, V. (2008). Recommendations on forest seed base of the most perspective non-native tree plants establishment. In Recommendations on forest seed grooving questions (pp. 1-34). Kharkiv: Ukrainian Research Institute of Forestry and Forest Melioration (in Ukrainian).

Molotkov, P., Patlay, I., Davyidova, N., Shchepotev, F., Iroshnykov, A., V, Mosyn... Myliutyn, L. (1982). Forest trees breeding. Moscow: Forest industry (in Russian).

Nikitin K. (1953). Growth and productivity of larch in the Ukrainian SSR. Scientific bulletin of Kiev Forestry Institute, 2, 39-67 (in Russian).

Patlay I. (1979) Larch provenance test in the Left-bank forest-steppe of Ukraine. Forestry and woodworking industry, 3 (101), 14-16 (in Ukrainian).

Patlaj, I., Molotkov, P. (1994). The method of forest species varieties testing in Ukraine. Kyiv: Harvest (in Ukrainian).

Shvydenko, A., Savich, Yu., Strochinsky, A., Polyakov, V., \& Kanunnikov, N. (1987). Normative reference materials for biometric measurements the forests of Ukraine and Moldavia. Kiev: Harvest (in Russian).

The method of expert examination of the group of decorative, ethereal, medicinal, forest plant varieties for suitability to spread in Ukraine (2014). Kyiv: according to the Tkachik S. scientific edition (in Ukrainian).

Volosyanchuk, R. T., Los, S. A., Torosova, L. O., Kuznecova T., Tereshchenko L., Neyko I. \& Grygoryeva, V. (2003) Methodological approaches to the estimation of gene pool conservation in situ 
units of the broadleaves tree species and their actual conditions in the Left-bank forest steppe of Ukraine. Forestry and forest melioration, 104, 50-57 (in Ukrainian).

Willougby, I., Stokes V., Poole J., White J., \& Hodge S. (2007). The potential of 44 native and nonnative species for woodland creation on a range of contrasting sites in lowland Britan. Forestry, 80 (5), 531-553.

Wysotska N. (2013). Methodology of complex evaluation of Picea Dietr. species introduction success. Forestry and forest melioration, 122, 56-62 (in Ukrainian).

\section{Комплексная оценка перспективности видов и гибридов лиственницы для условий Лесостепи Украины}

\author{
С. А. Лось' ${ }^{1}$ В.Г. Григорьева ${ }^{2}$ В.П. Самодай³, \\ І.С. Нейко ${ }^{4}$
}

Обобщены данные по комплексной оценке лесных культур видов и гибридов лиственницы в лесных культурах Лесостепи Украины. Исследование проведено в трех областях Украины - Харьковской (ГП «Харьковская ЛНИС», ГП «Гутянский лесхоз»), Сумской (ГП «Тростянецкий лесхоз», ГП «Свесский лесхоз»), Винницкой (ГП «Винницкий лесхоз», ГП «Винницкая ЛНИС»). В древостоях возрастом 52-124 года заложено десять пробных площадей. Подавляющее большинство древостоев расположено в лесостепной природной зоне, за исключением ГП «Свесский лесхоз», расположенного в Полесской природной зоне.

Лось Светлана Анатольевна - член-корреспондент Лесной академии наук Украины, кандидат сельскохозяйственных наук, заведующий лабораторией селекции. Украинский научноисследовательский институт лесного хозяйства и агролесомелиорации им. Г. Н. Высоцкого, ул. Пушкинская, 86, г. Харьков, 61024, Украина. Тел.: 057-707-80-77, +38-097-138-97-92. E-mail: svitlana_los@ukr.net

2 Григорьева Виктория Георгиевна - научный сотрудник ГП «Харьковская лесная научно-исследовательская станция» Украинского научно-исследовательского института лесного хозяйства и агролесомелиорации им. Г. Н. Высоцкого, ул. Пушкинская, 86, г. Харьков, 61024, Украина. Тел.: 057-707-80-30. E-mail: grygorye@rambler.ru

Самодай Вячеслав Петрович - кандидат сельскохозяйственных наук, старший научный сотрудник Краснотростянецкого отделення Украинского научно-исследовательского института лесного хозяйства и агролесомелиорации им. Г. Н. Высоцкого, ул. Нескучанская, 15, г. Тростянец Сумской обл., 42600, Украина. Тел.: +38-067-105-46-42. E-mail: samodayv@ukr.net

4 Нейко Игорь Степанович - кандидат сельскохозяйственных наук, заместитель директора ГП «Винницкая лесная научно-исследовательская станция» Украинского научноисследовательского института лесного хозяйства и агролесомелиорации им. Г. Н. Высоцкого, ул. Максимовича, 39, г. Винница, 21036, Украина. Тел.: +38-096-273-63-67. E-mail: ihor_neyko@ukr.net
Объект исследования - интродукция видов и гибридов рода Larix L. Цель исследований - оценка успешности интродукции видов и гибридов лиственницы в лесных культурах Лесостепи Украины.

В условиях Лесостепи Украины в половине случаев показатели видов и гибридов лиственницы превышают табличные показатели как дуба черешчатого, так и сосны обыкновенной по диаметру. В подавляющем большинстве случаев лиственница растет по высоте на уровне сосны или незначительно отстает от нее, одновременно превышая аналогичные показатели дуба черешчатого. Климатические условия Винниччины и Сумщины благоприятны для роста и развития лиственниц, тогда как длительные периоды засухи на Харьковщине влияют на них отрицательно. Существенного влияния типов лесорастительных условий на рост лиственниц не отмечено, но таксационные показатели древостоев в более богатых условиях $\left(D_{2}\right)$ в большинстве случаев несколько выше.

По результатам комплексной оценки лиственничных древостоев возрастом 52-124 года в трех областях Украины подавляющее их большинство оказались перспективными, что подтверждает пригодность лиственниц для создания лесных культур, защитных насаждений и озеленения в условиях Сумской и Винницкой областей. В условиях Харьковщины виды и гибриды лиственниц пригодны для создания защитных насаждений и озеленения.

Для более широкого внедрения видов и гибридов лиственницы в лесное хозяйство необходимо расширение лесосеменной базы, в частности с использованием репродуктивного материала плюсовых и лучших деревьев, отобранных у обследованных древостоях.

Ключевые слова: климат; интродукция; лесные культуры; таксационно-селекционные показатели; перспектива использования. 


\section{Complex assessment of larch species and hybrids perspectives for the Forest-Steppe of Ukraine conditions}

\section{S. Los ${ }^{1}$, V.G. Grygoryeva², V. Samoday ${ }^{3}$, I. Neyko ${ }^{4}$}

Data on the integrated assessment of larch species and hybrids forest plantations in the Forest-Steppe of Ukraine are summarized. The research was carried out in three regions of Ukraine - Kharkiv (State Enterprise "Kharkiv FRS", Guty Forest State Enterprise), Sumy (Trostyanets and Swesa Forest State Enterprises), Vinnytsya (Vinnytsa Forest State Enterprise, Vinnytsya FRS). In forest stands of 52-124 years 10 trial plot were laid. The vast majority of the stands are located in the

Svitlana Los - Corresponding Member of the Forestry Academy of Sciences of Ukraine, PhD in Agricultural Sciences, Head of laboratory of forest tree breeding of Ukrainian Research Institute of Forestry and Forest Melioration named after G. M. Vysotsky, Pushkinska str., 86, Kharkiv, 61024, Ukraine. Tel.: 057-707-80-77, +38-097-138-97-92. E-mail: svitlana_los@ukr.net

Viktoria Grygoryeva - researcher of Kharkiv forest experimental station of Ukrainian Research Institute of Forestry and Forest Melioration named after G. M. Vysotsky, Pushkinska str., 86, Kharkiv, 61024, Ukraine. Tel.: 057-707-80-30. E-mail: grygorye@ rambler.ru

Vyacheslav Samoday - PhD in Agricultural Sciences, senior researcher of Krasnotrostyanec department of Ukrainian Research Institute of Forestry and Forest Melioration named after G. M. Vysotsky, Neskushanska str., 15, Trostyanec of Sumy region., 42600, Ukraine.Tel.: +38-067-105-46-42. E-mail: samodayv@ukr.net

4 Ihor Neyko - PhD in Agricultural Sciences, vicedirektor of Vinnitsa forest experimental station of Ukrainian Research Institute of Forestry and Forest Melioration named after G. M. Vysotsky, Macsimovisha str., 39, Vinnitsa, 21036, Ukraine. Tel.: +38-096-273-6367. E-mail: ihor_neyko@ukr.net
Forest-Steppe natural zone, except for Swesa Forest State Enterprise, located in the Polissya natural zone.

The object of the study is the forest plantations of species and hybrids of the genus Larix L.

The aim of the research - assessment of the introduction success of larch species and hybrids in forest plantations in the Forest-Steppe of Ukraine.

In the forest-steppe of Ukraine, in half the cases, the parameters of larch species and hybrids exceed the table indexes of both English oak and Scotch pine by diameter. In the overwhelming majority of cases, larch grows by height is at the level of the pine or slightly behind it. And at the same time it exceeds the parameters of the oak.

Climatic conditions of Vinnytsya and Sumy regions are suitable for larches growth and development, while long periods of drought in the Kharkiv region affect them negatively. Significant effects of forest growing conditions have not been observed, but the characteristics of the stands in the richer conditions $\left(D_{2}\right)$ in the majority cases is slightly higher.

According to the results of the complex evaluation of the forest sands of the age of 52-124 years in three regions of Ukraine the vast majority of them proved to be perspective, which confirms the suitability of larch for the planting forest stands, protective plantations and landscaping in the Sumy and Vinnytsya regions. In the conditions of the Kharkiv region, species and hybrids of larch are suitable for the planting of protective plantings and landscaping.

For the more large scale implementation of larch species and hybrids in the forestry, it is necessary to expand the forest seed base, in particular, using plus and best trees, selected in the surveyed tree stands.

Key words: climate; introduction; forest plantation; biometric-selection indicators; perspectives of use. 